\title{
ANALISIS DAN DESAIN SISTEM INFORMASI EKSPEDISI CARGO LAUT PADA PT ARTAS BANGUN SARI
}

Tupan Tri Muryono

Jurusan Sistem Informasi, STMIK Widuri

Jl. Palmerah Barat No.353, Jakarta Selatan12210 Indonesia

e-mail: tupantm@yahoo.com

Agus Budiyantara

Jurusan Tknik Informatika, STMIK Widuri

Jl. Palmerah Barat No.353, Jakarta Selatan12210 Indonesia

e-mail: agusbudiyantara@yahoo.co.id

\begin{abstract}
ABSTRAKSI
Penelitian ini bertujuan untuk mengetahui prosedur sistem informasi berjalan dan mendesain sistem informasi ekspedisi cargo laut serta dapat memberikan solusi yang mencakup aktivitas pendataan costumer dan data muatan, invoicing, pembuatan perjanjian angkutan laut serta berita acara serahterima muatan.Metode penelitian ini menggunakan pendekatan kualitatif dengan teknik analisisentityrelationship model (ERM) dan system development life cycle (SDLC) dengan model air terjun (waterfall). Teknik pengumpulan datamenggunakan observasi dan wawancara terstukrtur kepada sekretaris dan pimpinan perusahaan. Simpulan dari hasil penelitian menunjukkan bahwa penggunaan sistem informasi ekspedisi cargo laut dapat membantu dalam menyelesaikan masalah yang terdapat di perusahaan tersebut.
\end{abstract}

Kata Kunci: analisis dan desain, sistem informasi ekspedisi cargo laut 


\section{PENDAHULUAN}

\subsection{Latar Belakang Masalah}

Usaha bisnis jasa pengiriman yang beroperasi di wilayah-wilayah antar pelabuhan atau dikenal dengan istilah kata "ekspedisi cargo laut". Bisnis ini cukup menjanjikan jika dikelola dengan baik. Bisnis kargo laut telah menjadi alternatif baik pengusaha perorangan maupun badan usaha sejak dahulu dan dipandang lebih menguntungkan karena perhitungan faktor harga menggunakan kubikasi / kilogram dibagi dengan harga tertentu sebagai biaya pengiriman. Di sisi lain, banyaknya peraturan dan prosedur perizinan yang membentengi pengusaha sehingga berdampak pada terjadinya peningkatan biaya yang signifikan. Penggunaan perangkat komputer dan sistem informasi yang terintegrasi akan menjadi solusi bagi pengusahan ekspedisi cargo lautagar tetap sustain di era informasi saat ini.

Kebutuhan untuk menghasilkan informasi yang cepat dan tepat sangat dibutuhkan oleh pihak PT Artas Bangun Sari, selanjutnya disebut "perusahaan" yang bergerak pada bidang penyedia dan jasa pengiriman bahan bangunan menggunakankapal layar motor (KLM). Sistem kerja perusahaan saat ini masih manual dan belum mengolah data menggunakan sistem informasi yang terkomputerisasi. Kendala-kendala yang masih sering dihadapi di lapangan diantaranya adalah pembuatan dokumen-dokumen serta laporan pembayaran dan berita acara serah-terima muatan yang dituliskan dalam bentuk format yang tidak baku. Costumer harus menghubungi pimpinan perusahaan via telepon atau bertemu langsung di kantor untuk melakukan transaksi secara langsung untuk memproses pengisian dan muatan kapal. Di samping itu, costumer juga tidak mengetahui keberadaan barang / muatan ekspedisi pada suatu titik koordinat secara pasti sehingga harus mendapatkan informasi secara langsung dari pimpinan perusahaan.Oleh karena itu, sangat diperlukan perancangan suatu sistem berbasis web yang dapat memudahkan costumer untuk mengetahui informasi ataupun keberadaan barang / muatan yang sedang dikirim, pembuatan output yang berupa beritaacara pengiriman muatan dan perjanjian pengangkutan laut dengan costumer.

Perjanjian Pengangkutan Laut merupakan hubungan antara pengangkut laut pada umumnya dalam hubungan hukum antara pengangkut dengan pemakai jasa pengangkutan yang berkedudukan sama tinggi atau koordinasi (geeoordineerd), tidak seperti dalam perjanjian perburuhan, dimana kedudukan para pihak tidak sama tinggi atau kedudukan subordinasi (gesubordineerd). Perjanjian ini merupakan awal dari tahapan ekspedisi cargo laut dengan costumer, dokumen ini masih dibuat dengan teks berbantuan mesin tik yang diakhiri dengan pembubuhan tanda tangan dan cap perusahaan sebagai konfirmasi / verifikasi data. Setelah proses input data tersebut, maka dihasilkan output berita acara pengiriman barang yang nantinya akan dikirimkan melalui pos ke costumer sesuai gudang atau tujuan alamat pengiriman apabila kapal telah berangkat.Setelah barangtiba dan dilakukan bongkar-muatoleh costumer di pelabuhan tujuan ekspedisi, maka perusahaan akan mendapatkan berita acara kembali sebagai bukti barang / muatan kapal telah diserahkan.

\subsection{Tujuan Penelitian}

Penelitian ini bertujuan untuk mengetahui prosedur dan menganalisis sistem informasi berjalanserta mendesain sistem informasi "Ekspedisi Cargo Laut"pada PT Artas Bangun Sari. Selain itu, penelitian ini juga diharapkan dapat memberikan solusi untuk mengidentifikasi keberadaan barang ekspedisi dalan muatan KLM pada titik koordinat tertentu dengan perangkat teknologi informasi.

\subsection{Kerangka Teoritis}

Sistem informasi terdiri dari input (instruksi dan data) dan output (kalkulasi dan laporan) yang diperoleh dengan cara mengumpulkan, menganalisis, memproses, menyimpan, dan menyebarkan informasi untuk tujuan tertentu. Pengirimanbarang merupakan kegiatan yang dilakukan oleh seseorang atau sekelompok orang dengan landasan faktor material melalui sistem, prosedur dan metode tertentu dalam rangka usaha memenuhi kepentingan orang lain sesuai dengan haknya. Sistem informasi tersebut ditujukan untuk mendukung proses bisnis dan memberikan pelayanan secara efektif dan efisien kepada costumer. Timbalbalik perusahaan dihitung berdasarkan cargo berat berdasarkan timbangan (actual weight) dengan suatu metode yang telah disetujui dalam perjanjian pengangkutan laut.

\section{METODE PENELITIAN}

Penelitian ini menggunakan metode deskriptif analitik dengan melakukan teknik observasi dan wawancara. Pengumpulan datadilakukan untuk mengidentifikasi sistem informasiberjalan dan kebutuhan pengguna yang bersumber dari hasil wawancara melalui keyinformanseperti sekretaris dan pimpinan perusahaan. Desain sisteminformasi ekspedisi cargo lautdibangun dengan metode system development life cycle (SDLC)dengan model air terjun (waterfall).

Model Waterfall SDLC adalah proses pengembangan perangkat lunak berurutan dimana suatu pengembangan dianggap mengalir semakin ke bawah (mirip dengan air terjun) melalui daftar fase yang harus dijalankan agar berhasil membangun perangkat lunak komputer. 


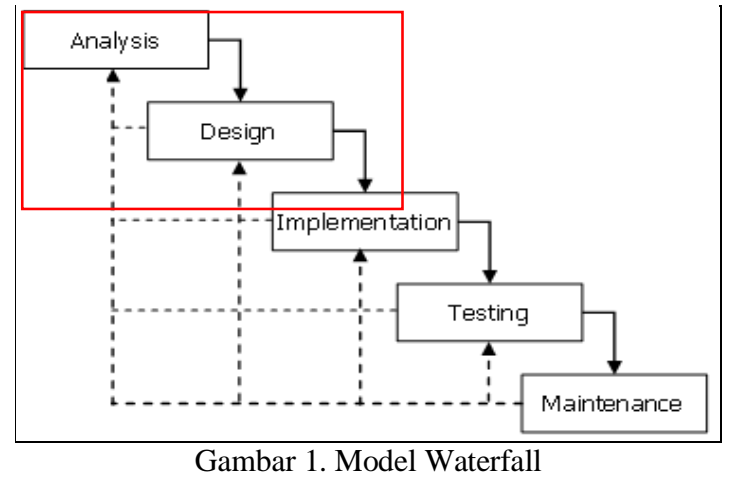

Tahapan kegiatan desain sistem informasi pada riset ini meliputi:

Fase Analisis.Deskripsi lengkap dan komprehensif dari perilaku perangkat lunak yang akan dikembangkan. Faseini melibatkan analis sistem dan bisnis perusahaan untuk mendefinisikan baik persyaratan fungsional maupun non-fungsional. Persyaratan fungsional dideskripsikan dengan menggunakan kasus penggunaan yang menggambarkan interaksi pengguna dengan perangkat lunak. Fase ini dikenal dengan istilah software requirements specification (SRS).

Fase Desain.Proses perencanaan dan solusi pemecahan masalah dalam bentuk penetapan perangkat lunak. Faseini melibatkan pengembangan perangkat lunak dan suatu rancangan untuk menentukan rencana solusi yang meliputi desain algoritma, desain arsitektur perangkat lunak, skema konseptual basis data dan desain diagram logis, desain konsep, desain antarmuka pengguna grafis, dan definisi struktur data.

Fase Implementasi.Realisasi persyaratan bisnis dan spesifikasi desain menjadi program yang dapat dieksekusi secara nyata dalam bentukbasis data, situs web atau komponen perangkat lunak melalui pemrograman dan susunannya.Fase ini merupakan kodifikasiyang dikompilasi menjadi aplikasi operasional, dimana file basis data dan teks dibuat.

Fase Pengujian. Verifikasi dan validasi yang merupakan proses untuk memeriksa bahwa solusi perangkat lunak telah memenuhi persyaratan dan tujuan dari spesifikasi asli yang dimaksudkan. Verifikasi adalah proses mengevaluasi perangkat lunak untuk menentukan apakah produk dari fase pengembangan yang diberikan telah memenuhi kondisi yang ditetapkan pada fase awal. Sementara, validasi adalah proses evaluasi perangkat lunak selama atau pada akhir proses pengembangan untuk menentukan apakah telah memenuhi persyaratan yang ditetapkan.

Fase Pemeliharaan. Proses memodifikasi solusi perangkat lunak setelah implementasi dan tahap pengujian untuk memperbaiki keluaran (output), kesalahan (error), dan meningkatkan kinerja dan kualitas. Kegiatan pemeliharaan lainnya dapat dilakukan dalam fase ini termasuk mengadopsi perangkat lunak ke lingkungan sistem, mengakomodasi kebutuhan pengguna baru, dan meningkatkan keandalan perangkat lunak.

\section{HASIL PENELITIAN}

\subsection{Riwayat Perusahaan}

PT. Artas Bangun Sari adalah salah satu perusahaan jasa ekspedisi cargo laut dan penyediabahan bangunan milik swasta perorangan yang berdomisili di Jl Pelabuhan Kalibaru 16-17 Jakarta - 14110. Sejak perusahaan berdiri, perusahaan hanya memiliki 2 (dua) buah KLM yang memiliki pangkalan di dermaga Gresik, Jawa Timur dengan rute utama, yaitu Pelabuhan Kumai - Kalimantan Tengah, Pelabuhan Tanah Merah - Kalimantan Selatan, Pelabuhan Panjang - Lampung,dan Pelabuhan Samarinda - Kalimantan Timur. Jenis muatan ekspedisi seperti kernel (biji sawit), pupuk, cengkeh dan barang komoditas lainnya. Lamanya hari bongkar-muat muatan biasanya \pm 4 hari ditambah jarak tempuh antar pelabuhan.

\subsection{Analisis Kebutuhan Sistem}

Adapun proses bisnis dan alur informasi sistem informasi ekspedisi cargo laut yang sedang berjalan di PT Artas Bangun Sari dari proses pendataan penyewa(costumer), perjanjian angkutan laut, berita acara bongkar-muat dan pembuatan laporan dijelaskan sebagai berikut:

- Pendataan Costumer; Costumer melakukan pemesanan atas ruangan kapal untuk muatan yang dikehendaki via telepon ke kantor perusahaan / secara langsung ke pimpinan. Sekretaris mencatat data costumer dan jenis muatan yang dipesan. Selanjutnya,nahkoda / kapten KLMmengkonfirmasi posisi titik koordinat kapal kepada Sekretaris.

- Perjanjian Angkutan Laut (PAL); Pimpinan perusahaan membuat suatu perjanjian dengan costumer. Perjanjian Angkutan Laut ini memuat kesepakatan-kesepakatan yang meliputi jenis muatan, lamanya hari bongkar-muat, dan sistem pembayaran serta hal-hal lainnya yang tertuangdalam perjanjian tersebut. Setelah pimpinan perusahaan menandatangani danmenunjuk bagian penanggungjawab ekspedisi, maka perjanjian tersebut dikirimkan ke costumer untuk ditandatangani dan diproses.

- Pembayaran; Sekretaris membuat surattagihan (invoice) yang ditujukan kepada costumer.Selanjutnya, costumer melakukan transaksi pembayaran.

- Berita Acara Serah-Terima Muatan. Penanggungjawab perusahaan mengirimkanlampiran berita acara serah terima muatan kepadacostumer. Berita acara ini berfungsi sebagai bukti bahwa kapal telah berangkat dari pelabuhan muat dan dikirimkan melalui pos ke costumer sebagai penerima tujuan pengiriman apabila kapal telah berangkat. Costumer selanjutnya akan mengkonfirmasi berita acara tersebut ketika barang / muatan telah tiba di pelabuhan tujuan.

Sistem informasi yang berjalan pada ekspedisi cargo 
laut di PT Artas Bangun Sari masihmenggunakan bentuk fisik atas pendataan costumer yang belum dibuatdalam format baku dengan pengkodean costumer sehinggaproses pengolahan dan pencarian data ekspedisi belum terarsipkan dalam bentuk file komputer. Keberadaan koordinat kapal tidak dapat diketahui secara pasti sehingga costumer harus menghubungi kantor atau pimpinan perusahaan secara langsung via-telepon. Oleh karena itu, dibutuhkan sistem informasi ekspedisi cargo laut yang terkomputerisasi untuk memudahkan administrasipemrosesan data costumer, mengetahui posisi muatan dengan perangkat teknologi informasisertapembuatan laporan-laporan seperti laporan Perjanjian Angkutan Laut (PAL) dan berita acara serah-terima muatan kapal.

\subsection{Desain Sistem}

Desain sistem informasi ekspedisi cargo laut yang telah dianalisis sebelumnya dibuatkan ke dalam diagram konteks usulan tetap melalui interaksi 3 (tiga) entitas pada gambar berikut ini:

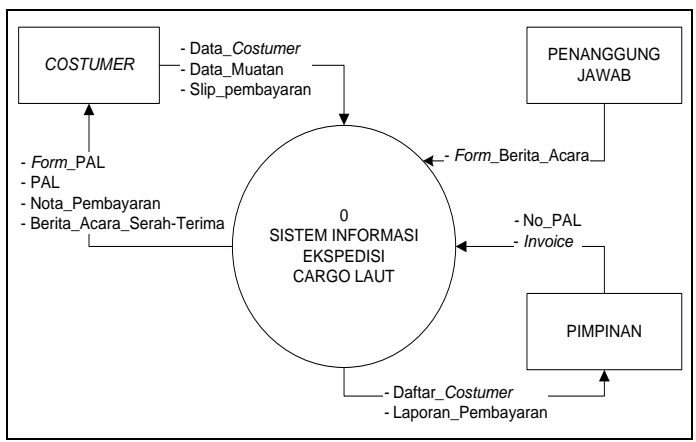

Gambar 2. Diagram Konteks Usulan

Entitas costumer merupakan sumber data yang akan diolah oleh sistem dengan menginputkan nama costumer, alamat, nomor telepon, dan upload dokumen-dokumen sepertiSurat Izin Usaha Perdagangan (SIUP) Tanda Daftar Perusahaan (TDP), dan Nomor Pokok Wajib Pajak (NPWP) sebagai penerima akhir yang dihasilkan oleh sistem informasi ekspedisi cargo laut yaitu Perjanjian Angkutan Laut (PAL), invoice dan berita acara serah-terima muatan kapal. Pimpinan perusahaan menginputkan nomor PAL dan membuat invoice yang menghasilkan daftar costumerdan laporan pembayaran. Selain itu, penanggungjawab setelah menerima dokumen PALjuga membuat form berita acaraekspedisi cargo lautsebagai bukti atas bongkar-muat barang di pelabuhan. Hasil rancangan skema diagram konteks yang diusulkan, dituangkan ke dalam entity relationship diagram (ERD) dan ditransformasikan ke dalam logical record structure (LRS) pada masing-masing gambar berikut ini:

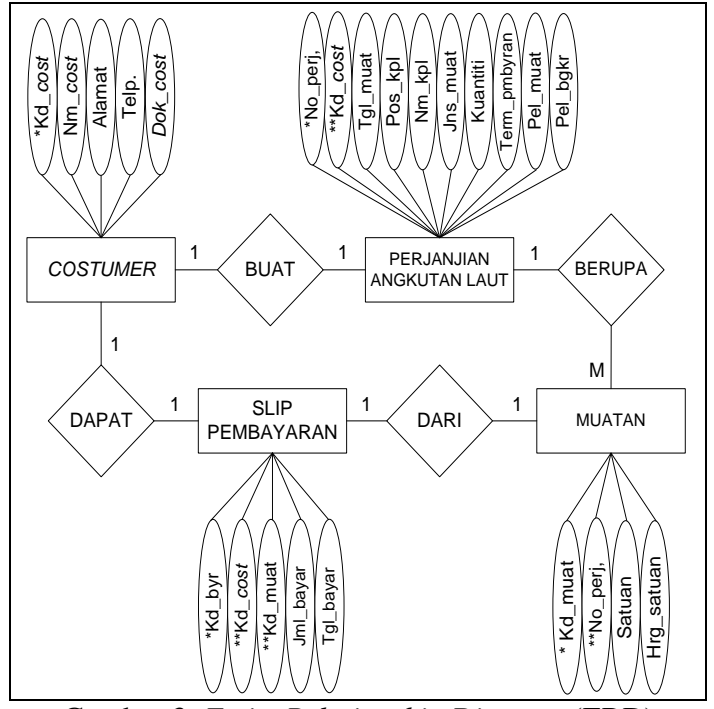

Gambar 3. Entity Relationship Diagram (ERD)

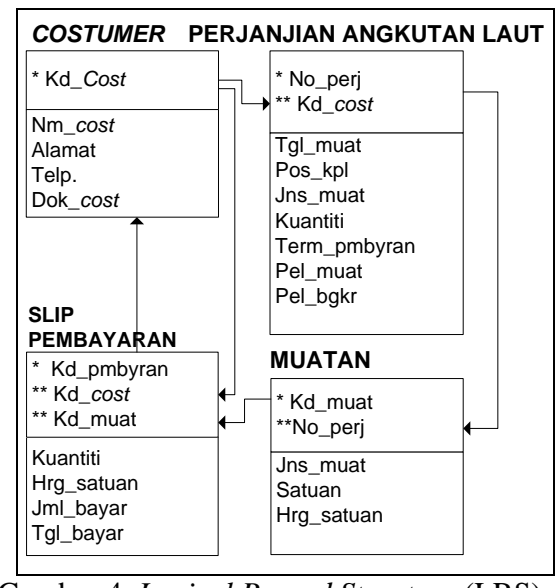

Gambar 4. Logical Record Structure (LRS)

Hasil rancangan skema LRS yang diusulkan dalam sistem basis dataekspedisi cargo laut di atas menunjukkan representasi dari struktur record pada tabel-tabel yang terbentuk dari hasil relasi antar himpunan entitas yang akan selalu berinteraksi dengan lingkungannya. Tabel costumer memiliki atributkd_mitra sebagai primary key dan menjadi master data dan menjadi foreign key pada tabel Perjanjian Angkutan Laut (PAL), tabel Muatan dan tabel Slip Pembayaran. Tabel Muatan memiliki field kd_muatan yang juga berfungsi sebagai primary key dan menjadi foreign key hanya pada tabel Slip Pembayaran. Interaksi ini ditujukan untuk mengkomunikasikan percakapan antara pengguna (user) data ke sistem, menampilkan output informasi kepada user atau dapat keduanya.

Layar dialog harus dibentuk agar instruksi dan bantuanbantuan serta output informasi selalu ditampilkan pada area yang sudah pasti. Penggunaan interface dapat diusulkan dengan menggunakan PHP berbasis web. Adapun desain struktur tampilan yang diusulkan dalam penelitian ini terdiri dari: 


\subsubsection{Desain Halaman Utama}

Desain halaman utama pada sistem informasi ekspedisi cargo laut dapat menggunakan fitur Menu "Home" yang memuatcompany-profile PT. Artas Bangun Sari, visi dan misi serta informasi-informasi lainnya, serta menambahkanGPS Tracking System pada salah satu fitur website, dimanadapatmemberikan informasi tentang keberadaan posisi kapal secara tepat dengan cara menandai titik koordinat yang terdapat pada GPS dan mencocokan pada peta.

\subsubsection{Rancangan Login}

Loginmerupakan hak akses setiapuserpada sistem informasi ekspedisi cargo laut yang nantinya diakses melalui web localhost.

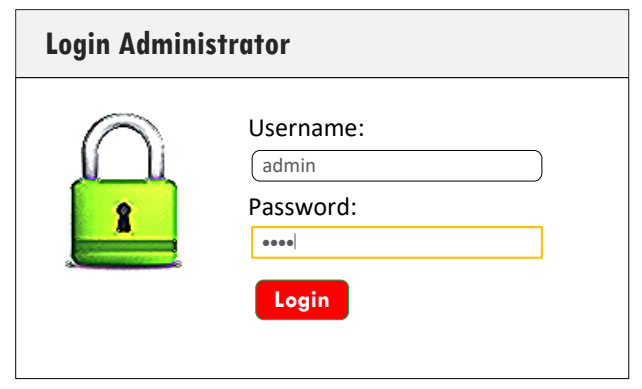

Gambar 5. Ilustrasi halaman Login Administrator

\subsubsection{Rancangan Layar Pendataan Costumer}

Rancangan layar ini dapat diakses nantinya oleh costumermelalui website resmi perusahaan.

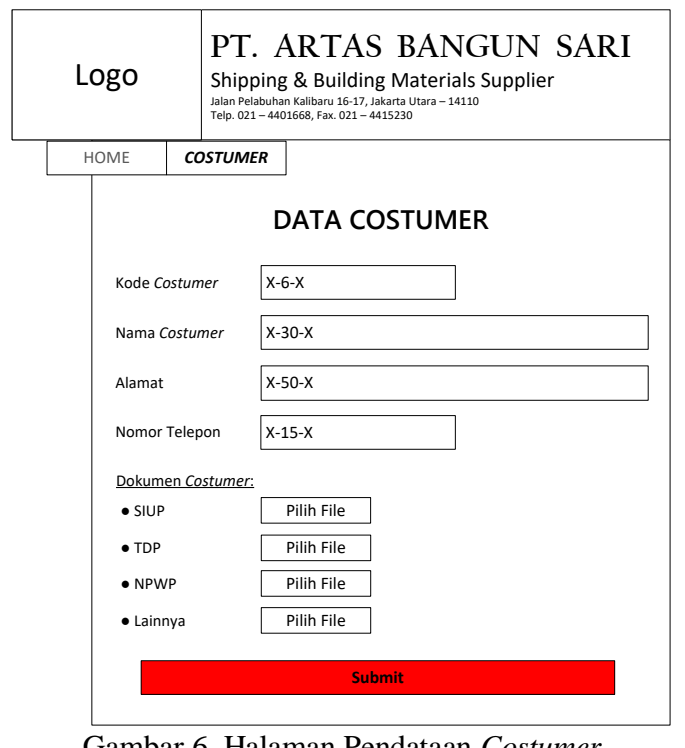

Gambar 6 menampilkan halaman utamayang harus diisi oleh costumer sebagai user. User dapat menginput data yang mencakup nama, alamat, dan nomor telepon. Selain itu, user meng-upload dokumen-dokumen seperti hasil scanning SIUP, TDP, NPWP dan lainnya. Jika data telah diisi dengan lengkap maka user dapat mengklik tombol "Submit".

\subsubsection{Rancangan Layer Pendataan Nomor Perjanjian Angkutan Laut (PAL)}

Rancangan layer ini dapat diakses nantinya oleh costumer setelah diverifikasi olehpimpinan perusahaanmelalui website resmi perusahaan.

\begin{tabular}{|c|c|c|}
\hline \multicolumn{2}{|l|}{ Logo } & $\begin{array}{l}\text { PT. ARTAS BANGUN SARI } \\
\text { Shipping \& Building Materials Supplier } \\
\text { Jalan Pelabuhan Kalibaru 16-17, Jakarta Utara - } 14110 \\
\text { Telp. 021 - } 4401668 \text {, Fax. } 021-4415230\end{array}$ \\
\hline \multicolumn{3}{|c|}{ Nomor Perjanjian Angkutan Laut (PAL) --> Entry } \\
\hline \multirow{3}{*}{\multicolumn{2}{|c|}{$\begin{array}{l}\text { Kode Costumer } \\
\text { Nama Costumer } \\
\text { Input No. PAL }\end{array}$}} & $x-6-x$ \\
\hline & & $x-30-x$ \\
\hline & & \\
\hline \multicolumn{3}{|c|}{ Input No. PAL } \\
\hline
\end{tabular}

Gambar 7 menampilkan halaman yang diakses melalui website resmi perusahaan yang nantinya akan diisi oleh pimpinan perusahaan sebagai user.User dapat menginput nomor PAL yang menjadi bukti bahwa costumer tersebut telah diverifikasi oleh pimpinan. Jika nomor perjanjian telah dinput dengan lengkap maka user dapat mengklik tombol "Verify".

\subsubsection{Rancangan Layer Data Muatan}

Rancangan layer ini dapat diakses nantinya oleh costumer perusahaanmelalui website resmi perusahaan.

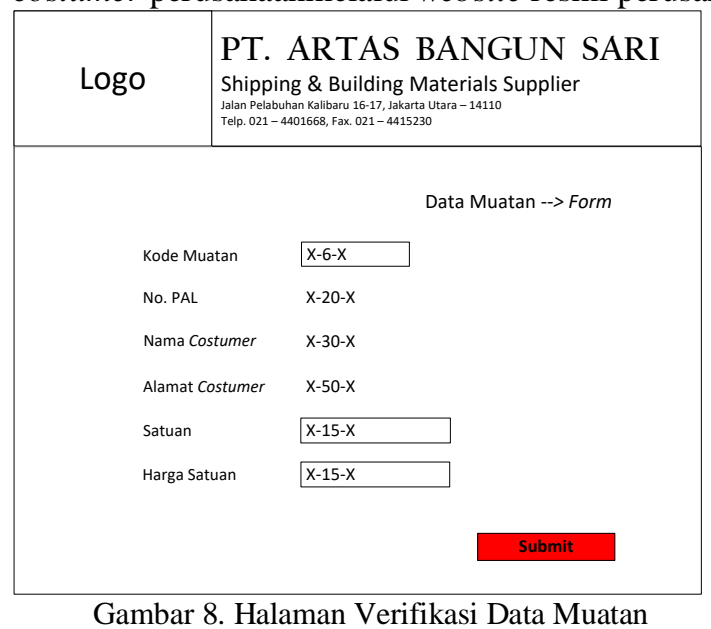

Gambar 8 menampilkan halaman yang diakses melalui website resmi perusahaan yang nantinya akan diisi oleh costumer sebagai user.User dapat menginput jenis satuan dan harga tiap satuan. Jika data muatan telah dinput dengan lengkap maka user dapat mengklik tombol "Submit". 


\subsubsection{Rancangan Layer Perjanjian Angkutan Laut}

perusahaan dengan costumer.

\begin{tabular}{|c|c|c|}
\hline Logo & \multicolumn{2}{|c|}{ 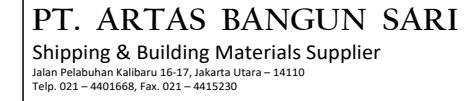 } \\
\hline \multicolumn{3}{|c|}{ PERJANJIAN ANGKUTAN LAUT } \\
\hline & Nomor Perjanjian & $x-25-x$ \\
\hline & Kode Costumer & $: x-6-x$ \\
\hline & Nama Costumer & $: x-30-x$ \\
\hline & Alamat & $: x-50-x$ \\
\hline & Tanggal Muat & dd-mm-yyyy \\
\hline & Posisi Kapal & $: x-20-x$ \\
\hline & Jenis Muatan & $x-15-x$ \\
\hline & Kuantiti & $x-6-x$ \\
\hline & Termin Pembayaran & $x-100-x$ \\
\hline & Pelabuhan Muat & $x-30-x$ \\
\hline & Pelabuhan Bongkar & $x-30-x$ \\
\hline
\end{tabular}

Gambar 9 menampilkan halaman yang memuat informasi mencakup hasil Perjanjian Angkutan Laut (PAL) yang meliputi nomor perjanjian costumer, tanggal muat, jenis muatan, posisi kapal, kuantiti, serta pelabuhan bongkar-muat kapal. Hasil perjanjian ini diberikan kepada masing-masing penanggungjawab sebagai dokumen bukti atas aktivitas bongkar-muat barang di pelabuhan.
Rancangan layer ini merupakan informasi output yang dihasilkan yaitu berupa Perjanjian Angkutan Laut antara

\section{SIMPULAN DAN SARAN}

Berdasarkan hasil penelitian yang diusulkan melalui desain sistem informasi ekspedisi cargo laut dapat menyelesaikan permasalahan terkait data muatan dengan mengidentifikasi barang ekspedisi yang termuat dalam Perjanjian Angkutan Laut (PAL). Pada halaman utama, hendaknya dilengkapi dengan fitur pada menu tracking-system pada website yang bekerjasama dengan vendor tertentu sehingga penanggungjawab dapatmengakses informasi tentang titik ordinat keberadaan posisi kapal secaralebih cepat dan tepat.

\section{DAFTAR PUSTAKA}

Bassil, Youssef, "A Simulation Model for the Waterfall Software Development Life Cycle," International Journal of Engineering \& Technology (iJET), vol. 5, no. 2, May 2012.

Pudyatmoko, Y. Sri, PERIZINAN "Problem dan Upaya Pembenahan", 2nd ed. Jakarta: PT Gramedia Widiasarana Indonesia, 2012.

Stellman, Andrew and Jennifer Greene. (2006). Applied Software Project Management, 2nd ed., Jamie Peppard, Ed. Sebastopol: O'Reilly Media, Inc...

Satika, Nur Dwi. (2014). Sistem Informasi Pengiriman Barang Berbasis Web dengan Metode Transhipment, Agustus 2014.

Sutarman, Pengantar Teknologi Informasi, 2nd ed. Jakarta: Bumi Aksara, 2012.

Utari, Sri. (1994). Pengangkutan Laut. Jakarta: Balai Pustaka, September 1994. 